\title{
Infectivity of aquabirnavirus strains to various marine fish species
}

\author{
Tadashi Isshiki ${ }^{1, *}$, Taizou Nagano $^{1}$, Satoru Suzuki ${ }^{2}$ \\ ${ }^{1}$ Kagawa Prefectural Fisheries Experiment Station, Takamatsu, Kagawa 761-0111, Japan \\ ${ }^{2}$ Centre for Marine Environmental Studies, Ehime University, Matsuyama, Ehime 790-8577, Japan
}

\begin{abstract}
To determine the infectivity of marine birnavirus (MABV) in various marine fish species, experimental infection was performed in combination groups of 5 fish species with 7 strains of MABV and 1 strain of infectious pancreatic necrosis virus (IPNV). Mortality was observed in yellowtail Seriola quinqueradiata and amberjack $S$. dumerili infected with MABV strains Y-6, Y-10K and H-1, but not in other infected species. MABV was reisolated from most combination groups, but the virus isolation rate and virus infectivity titer were often significantly different among groups with the same fish species or with the same virus strain. All MABV strains replicated well in makogarei Limanda yokohamae, but only slightly in tiger puffer Takifugu rubripes. IPNV also replicated in all fish species without causing death. The isolation rate and infectivity titer of IPNV were similar to or higher than those of non-virulent strains of MABV. In conclusion, the infectivity of MABV for different fish species is considered to change, which is an important factor in the development of the infection cycle of this virus among marine organisms.
\end{abstract}

KEY WORDS: Aquabirnavirus · Marine birnavirus - Infectious pancreatic necrosis virus · Marine fish $\cdot$ Infectivity $\cdot$ Experimental infection

\section{INTRODUCTION}

Aquabirnaviruses belong to a genus of the family Birnaviridae that possess a 2-segmented doublestranded RNA genome (Dobos et al. 1995). Infectious pancreatic necrosis virus (IPNV) is the type species of this genus. IPNV is an important pathogen associated with an acute and contagious disease in salmonids (Wolf 1988). A marine aquabirnavirus was first isolated from yellowtail, Seriola quinqueradiata, in Japan and named yellowtail ascites virus (YAV) (Sorimachi \& Hara 1985). Subsequently, YAV-like viruses have been isolated from various marine fishes, such as yellowtail (Nakajima et al. 1993), Japanese flounder Paralichthys olivaceus (Kusuda et al. 1989), red sea bream Pagrus major (Kusuda et al. 1994), tiger puffer Takifugu rubripes (Kamakura et al. 1995), and other species (Kusuda et al. 1993, Suzuki et al. 1997a). These aquabirnaviruses from marine fish species in Japan were tentatively named marine birnaviruses (MABVs)

*E-mail: kagawafdl@pop06.odn.ne.jp by Hosono et al. (1996) because they are distinguishable from IPNV by serotyping (Kusuda et al. 1993, Hosono et al. 1994) and genogrouping (Hosono et al. 1996). MABV infections have also occurred in shellfish species such as the jack knife clam Sinonovacura constricta (Suzuki et al. 1997b) and Japanese pearl oyster Pinctada fucata (Suzuki et al. 1998a,b) in Japan. The viral replication and protein expression of MABV in Japanese pearl oyster have been confirmed by electron microscopy and indirect fluorescent antibody technique (Kitamura et al. 2000). Recently, MABV or its genome has been detected in wild populations of various molluskan shellfish species in Japan (Suzuki \& Nojima 1999). The investigations above indicate that the host range of MABV is very broad. However, the infection cycle among various species is not clear. Transmissions of MABV from host to host need to be understood in order to suppress the diseases caused by MABVs and reduce the spread of MABVs in aquaculture environments. Moreover, it is important to know the virus infectivity in various hosts from the viewpoint of fish pathology. 
We report the infectivity of several aquabirnavirus strains, including MABV and IPNV, against some marine fish species. The mortality, virus isolation rate and infectivity titer were compared among experimental groups.

\section{MATERIALS AND METHODS}

Cell line. The CHSE-214 cell line (chinook salmon embryo; Lannan et al. 1984) was used in this study. This cell line was grown at $20^{\circ} \mathrm{C}$ in Eagle's minimum essential medium (Nissui, Japan) supplemented with $10 \%$ fetal bovine serum.

Virus strains. The aquabirnavirus strains used in this study are shown in Table 1. Seven strains of MABV and 1 strain of IPNV isolated from fish and shellfish cultured in various areas of western Japan during natural outbreaks were examined. Among them, an unpublished strain, KMKBV-9701, was isolated from hatchery-reared makogarei Limanda yokohamae juveniles (27 d old, average $10 \mathrm{~mm}$ in total length) collected during mass mortalities at a water temperature of $15^{\circ} \mathrm{C}$ in February 1997 in Kagawa Prefecture. Each strain was grouped into MABV or IPNV by genogrouping based on amino acid sequences in the VP2/NS junction region (Hosono et al. 1996). All these strains were propagated on CHSE-214 cells at $20^{\circ} \mathrm{C}$. The susceptibility of the CHSE-214 cell line at $20^{\circ} \mathrm{C}$ was nearly equal to all the used virus strains (data not shown).

Experimental fish. Five species of marine fish were examined: yellowtail (mean body weight $2.2 \mathrm{~g}$ ), amberjack Seriola dumerili (17.7 g), black sea bream, Acanthopagrus schlegeli (6.6 g), tiger puffer (3.0 g) and makogarei $(6.2 \mathrm{~g})$. These fishes were produced at Yashima Station of Japan Sea-Farming Association, Kagawa Prefectural Sea-Farming Center, or a private fish farm in Kagawa Prefecture.

Experimental infection. Twenty-five fish of each species were injected with $0.05 \mathrm{ml}$ of $10^{7.8}$ plaque forming units (PFU) $\mathrm{ml}^{-1}$ suspension of each virus strain, subcu- taneously for the tiger puffer and intraperitoneally for the other fish species. The controls for each fish species were injected with cell culture supernatant of noninfected CHSE-214 cells. After injection, each group was reared individually in $2000 \mathrm{l}$ aquaria with aeration for $10 \mathrm{~d}$. The water temperature was kept at $15^{\circ} \mathrm{C}$ for the makogarei group and at $20^{\circ} \mathrm{C}$ for the other fish species, which are the temperatures of the water that juveniles of each species usually inhabit in the field and at which natural outbreaks have frequently occurred.

Measurement of virus isolation rate and virus infectivity titer. A total of 12 dead and surviving fish at $10 \mathrm{~d}$ post-injection in each group were individually tested for virus infection. The viscera and brain of each fish were pooled and suspended in 9-fold volumes of Hanks' balanced salt solution (Nissui). The mixture was homogenized with a 10 to $50 \mathrm{ml}$ glass homogenizer (Iwaki, Japan) and centrifuged at $1761 \times g$ for $15 \mathrm{~min}$ at $4^{\circ} \mathrm{C}$. The supernatant was diluted with 4 -fold volumes of Hanks' balanced salt solution and filtered through a $0.45 \mu \mathrm{m}$ cellulose acetate membrane filter (Iwaki). The filtrate was inoculated onto a monolayer of CHSE-214 cells $\left(100 \mu \mathrm{l} \mathrm{well}{ }^{-1}\right)$ cultured in a 24 well tissue culture plate (Falcon, USA). The cells were incubated at $20^{\circ} \mathrm{C}$ for $10 \mathrm{~d}$ and examined for birnavirus specific cytopathic effect. In cases where there was a cytopathic effect, the culture supernatant was reinoculated to new cells to confirm the presence of a replicating agent. The isolated virus was identified as either MABV or IPNV by a neutralization test (Jung et al. 1999) using antisera against the MABV strain Y-6 and the IPNV strain VR299. The virus isolation rate was expressed as the number of fish infected out of 12 tested. The virus infectivity titer was determined by the plaque method with CHSE214 cells according to the suspension assay of Russell (1962) using an overlay medium containing $1 \%$ low melting point agarose (Gibco, USA). The plaque assay was performed in duplicate. Values above $10^{6.0} \mathrm{PFU} \mathrm{g}^{-1}$ were considered to be high based on previous observations in a survey of MABV in wild yellowtail fingerlings (Isshiki et al. 1989).

Table 1. Aquabirnavirus strains used in this study. Genotype was designated based on Hosono et al. (1996). IPNV: infectious pancreatic necrosis virus; MABV: marine birnavirus

\begin{tabular}{|lccccc|}
\hline Genotype & Strain & Origin (scientific name) & Year & Prefecture & Source \\
\hline MABV & Y-6 & Yellowtail (Seriola quinqueradiata) & 1985 & Kochi & Kusuda et al. (1993) \\
MABV & Y-10K & Amberjack (Seriola dumerili) & 1988 & Ehime & Kusuda et al. (1993) \\
MABV & H-1 & Japanese flounder (Paralichthys olivaceus) & 1986 & Ehime & Kusuda et al. (1989) \\
MABV & KMKBV-9701 & Makogarei (Limanda yokohamae) & 1997 & Kagawa & Unpubl. \\
MABV & TP-93 & Tiger puffer (Takifugu rubripes) & 1993 & Mie & Kamakura et al. (1995) \\
MABV & AY-98 & Ayu (Plecoglossus altivelis) & 1998 & Kochi & Jung et al. (1999) \\
MABV & JPO-96 & Japanese pearl oyster (Pinctada fucata) & 1996 & Ehime & Suzuki et al. (1998a) \\
IPNV & AM-98 & Amago salmon (Oncorhynchus macrostomus) & 1998 & Kochi & Jung et al. (1999) \\
\hline
\end{tabular}


Statistical analysis. The mortality, virus isolation rate and virus infectivity titer in all experimental groups were compared. To determine whether differences among the groups were significant, the mortality and virus isolation rates were analyzed by Fisher's exact probability test. The virus infectivity titer (mean value) was analyzed by 1-way ANOVA followed by TukeyKramer test. A probability level of $p<0.05$ was considered significant. Calculation was performed using the StatView computer program (SAS Institute Inc, Cary, North Carolina, USA).

\section{RESULTS}

\section{Mortality}

Mortality throughout $10 \mathrm{~d}$ in each experimental group is summarized in Table 2. Death occurred in yellowtail and amberjack groups infected with strains Y-6, Y-10K and H-1 within 3 d post-injection, but not in any other groups. Mortality was significantly higher in the yellowtail-Y-6 combination group than in other groups. Strains KMKBV-9701, TP-93, AY-98 and JPO96 were not lethal to any fish species. Mortality was zero in all fish species infected with the IPNV AM-98.

\section{Virus isolation from infected fish}

Viruses were isolated in 12 fish from each group, including dead fish and randomly selected surviving fish. As shown in Fig. 1, viruses were reisolated from most of the infected groups, except for the yellowtailJPO-96 and tiger puffer-KMKBV-9701 groups. For the MABV strains, the virus isolation rate was often significantly different within the yellowtail, amberjack, black sea bream and tiger puffer species. However, for the makogarei, all virus strains were isolated at a high rate, with no significant differences in the virus isolation rate. The virus isolation rate differed among

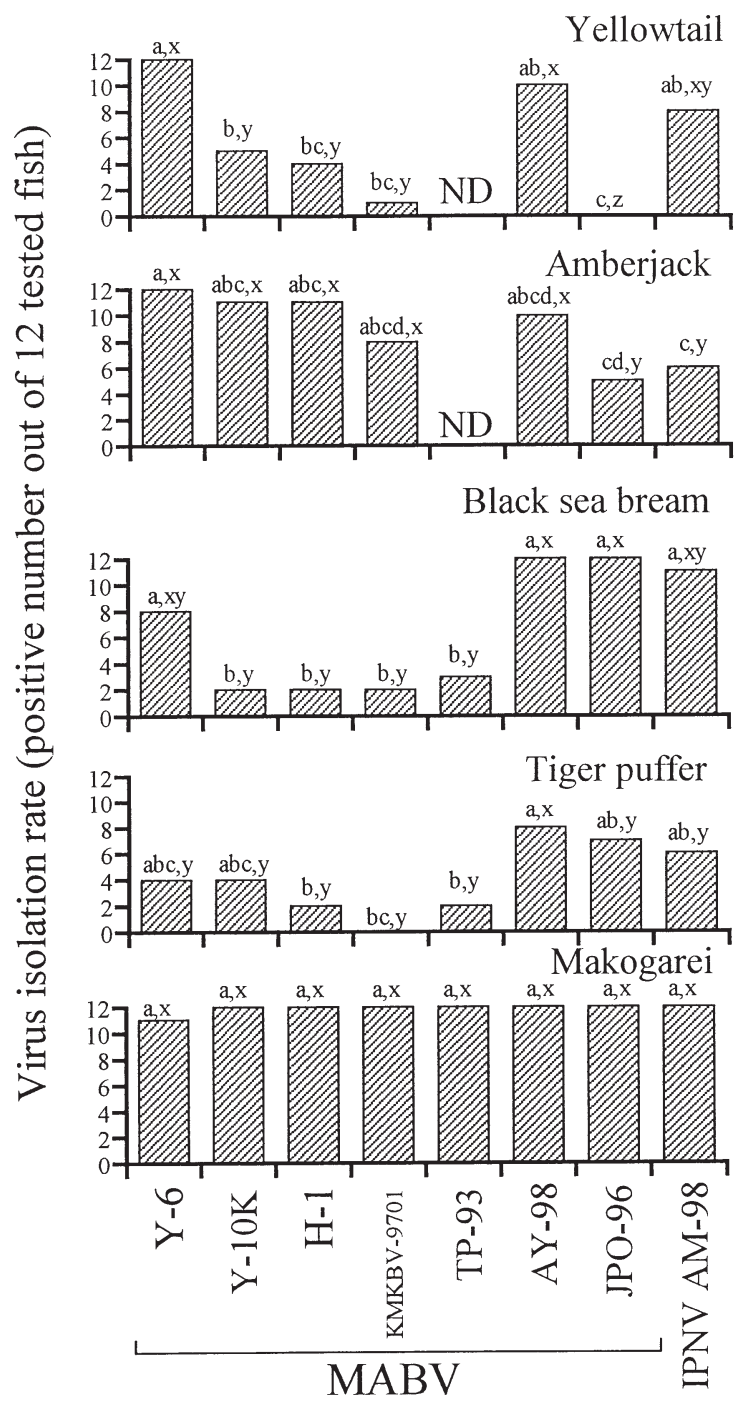

Fig. 1. Virus isolation rate in combination groups of 5 fish species with 7 strains of marine birnavirus (MABV) and 1 strain of infectious pancreatic necrosis virus (IPNV). Twelve fish of each group were tested for virus isolation. Data with different superscript letters are significantly different among groups with the ${ }^{a, b, c, d}$ same fish species $(p<0.05)$ and ${ }^{x, y, z}$ same virus strain $(\mathrm{p}<0.05)$. ND: injection trial was not done

Table 2. Mortality rates in combination groups of 5 fish species with 7 strains of MABV and 1 strain of IPNV. Data are number of dead fish out of 25 injected fish. Data with different superscript letters are significantly different among groups with the ${ }^{\mathrm{a}, \mathrm{b}}$ same fish species $(\mathrm{p}<0.05)$ and ${ }^{\mathrm{x}, \mathrm{y}, \mathrm{z}}$ same virus strain $(\mathrm{p}<0.05)$. ND: injection trial was not done

\begin{tabular}{|c|c|c|c|c|c|c|c|c|}
\hline \multirow[t]{2}{*}{ Fish species } & \multicolumn{8}{|c|}{ Virus strain } \\
\hline & Y-6 & $\mathrm{Y}-10 \mathrm{~K}$ & $\mathrm{H}-1$ & $\begin{array}{c}\text { MABV } \\
\text { KMKBV-9701 }\end{array}$ & TP-93 & AY-98 & JPO-96 & $\begin{array}{l}\text { IPNV } \\
\text { AM-98 }\end{array}$ \\
\hline Yellowtail & $16^{\mathrm{a}, \mathrm{x}}$ & $3^{\mathrm{b}, \mathrm{x}}$ & $2^{\mathrm{b}, \mathrm{x}}$ & $0^{\mathrm{b}, \mathrm{x}}$ & ND & $0^{\mathrm{b}, \mathrm{x}}$ & $0^{\mathrm{b}, \mathrm{x}}$ & $0^{\mathrm{b}, \mathrm{x}}$ \\
\hline Amberjack & $7^{\mathrm{a}, \mathrm{y}}$ & $3^{a b, x}$ & $4^{\mathrm{ab}, \mathrm{x}}$ & $0^{b, x}$ & ND & $0^{\mathrm{b}, \mathrm{x}}$ & $0^{\mathrm{b}, \mathrm{x}}$ & $0^{\mathrm{b}, \mathrm{x}}$ \\
\hline Black sea bream & $0^{\mathrm{a}, \mathrm{z}}$ & $0^{\mathrm{a}, \mathrm{x}}$ & $0^{\mathrm{a}, \mathrm{x}}$ & $0^{\mathrm{a}, \mathrm{x}}$ & $0^{\mathrm{a}, \mathrm{x}}$ & $0^{\mathrm{a}, \mathrm{x}}$ & $0^{\mathrm{a}, \mathrm{x}}$ & $0^{\mathrm{a}, \mathrm{x}}$ \\
\hline Tiger puffer & $0^{\mathrm{a}, \mathrm{z}}$ & $0^{\mathrm{a}, \mathrm{x}}$ & $0^{\mathrm{a}, \mathrm{x}}$ & $0^{\mathrm{a}, \mathrm{x}}$ & $0^{\mathrm{a}, \mathrm{x}}$ & $0^{\mathrm{a}, \mathrm{x}}$ & $0^{\mathrm{a}, \mathrm{x}}$ & $0^{\mathrm{a}, \mathrm{x}}$ \\
\hline Makogarei & $0^{\mathrm{a}, \mathrm{z}}$ & $0^{\mathrm{a}, \mathrm{x}}$ & $0^{\mathrm{a}, \mathrm{x}}$ & $0^{\mathrm{a}, \mathrm{x}}$ & $0^{a, x}$ & $0^{\mathrm{a}, \mathrm{x}}$ & $0^{\mathrm{a}, \mathrm{x}}$ & $0^{\mathrm{a}, \mathrm{x}}$ \\
\hline
\end{tabular}




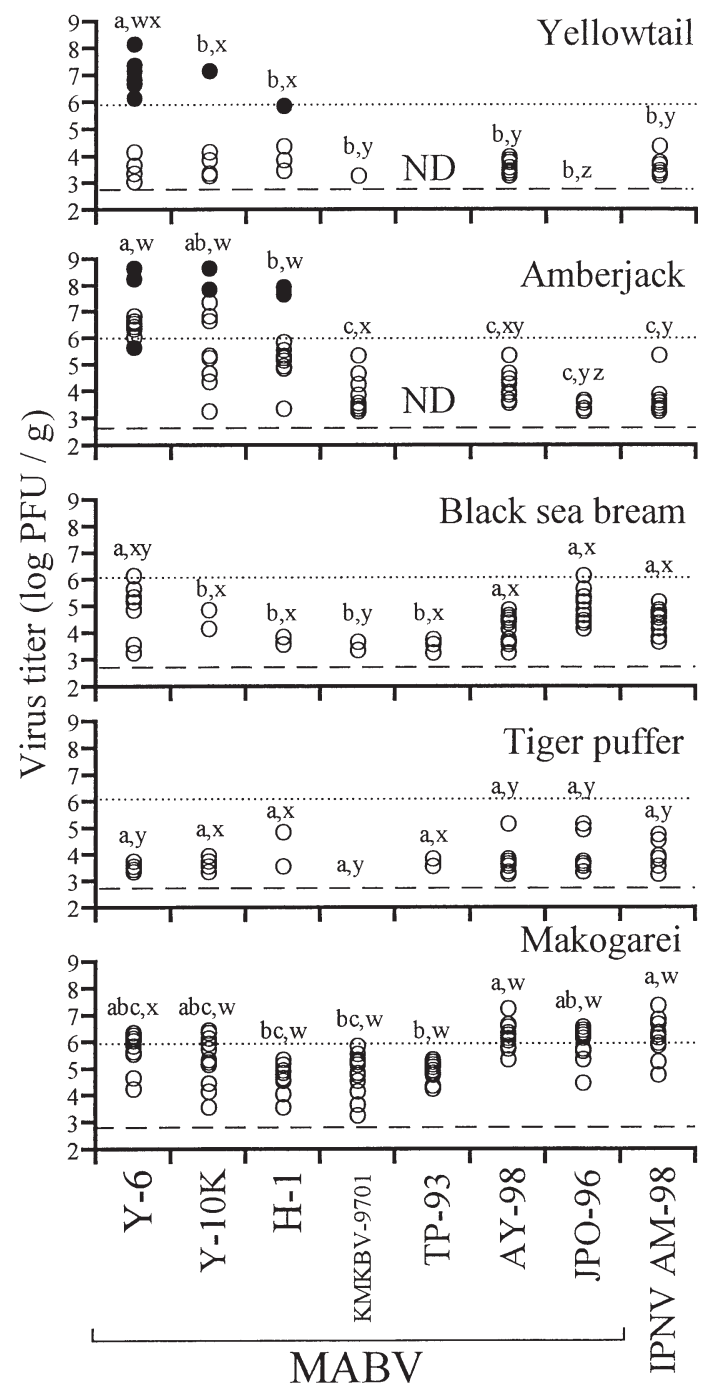

Fig. 2. Virus infectivity titer of individual fish in combination groups of 5 fish species with 7 strains of MABV and 1 strain of IPNV. Closed and open circles indicate data of dead and surviving fish, respectively. Means of data with different superscript letters are significantly different among groups with the $\mathrm{a}, \mathrm{b}, \mathrm{c}$ same fish species $(\mathrm{p}<0.05)$ and ${ }^{\mathrm{w}, \mathrm{x}, \mathrm{y}, \mathrm{z}}$ same virus strain $(\mathrm{p}<$ $0.05)$. Dotted lines indicate boundary value considered to be a high value $\left(10^{6.0}\right.$ plaque forming units [PFU] $\left.\mathrm{g}^{-1}\right)$. Dashed lines indicate the detection limit $\left(10^{2.7} \mathrm{PFU} \mathrm{g}^{-1}\right)$. ND: injection trial was not done

groups with the same virus strain, except for the AY-98 strain. Strains Y-6, Y-10K and KMKBV-9701 were isolated at high rates in the original hosts (yellowtail, amberjack and makogarei, respectively). However, the isolation rate of TP-93 was low in its original host (tiger puffer). In contrast, AY-98 was isolated at high rates in all fish species, although it was not lethal.

IPNV strain AM-98 was isolated from all fish species. The isolation rate was high in makogarei as well as all MABV strains. The virus isolation rate of the IPNV strain was similar to or higher than that of each MABV strain in all the fish species, except for one case where the rate for the virulent strain Y-6 of MABV was significantly higher than that for the IPNV strain in amberjack.

In both the MABV and the IPNV challenges, no correlation was observed between mortality and isolation rate.

\section{Virus infectivity titer}

The virus infectivity titers of individual fish in the experimental groups are shown in Fig. 2. For the MABV strains, high titers $\left(>10^{6.0} \mathrm{PFU} \mathrm{g}^{-1}\right)$ were obtained in most dead yellowtail and dead amberjack. Titers were below $10^{6.0} \mathrm{PFU} \mathrm{g}^{-1}$ in many surviving fish in most groups. In makogarei, some surviving fish injected with strains Y-6, Y-10K, AY-98 or JPO-96 had high titers, even though this species was not susceptible to any MABV or IPNV strains. The mean virus titers of each virus isolate often differed significantly within the yellowtail, amberjack, black sea bream or makogarei species. However, a different tendency was observed in groups of tiger puffer, which had a low titer in all virus strains with no significant differences in this titer. The mean virus titers of each fish-virus combination group differed significantly among fish species with the same virus strain. All strains except Y6 had significantly higher titers in makogarei than in the other species. Strains Y-6, Y-10K and KMKBV-9701 also had higher titers in each original host, but TP-93 did not, which is similar to the pattern seen in the virus isolation rate. The infectivity titer of AY-98 was low even though the isolation rate was high.

For IPNV, titers were high from some surviving makogarei, but not from other fish species. The mean infectivity titers of each fish-IPNV combination group were similar to or higher than those of most fish-MABV combination groups in all fish species, which is similar to the pattern seen in the virus isolation rate. However, the titers were lower than those of the yellowtail-Y-6, amberjack-Y-6, amberjack-Y-10K and amberjack-H-1 groups showing mortality. The infectivity titer in the makogarei-IPNV group was higher than that in the other fish-IPNV groups.

\section{DISCUSSION}

Strains Y-6, Y-10K and H-1 had a lethal effect in yellowtail and amberjack, which belong to the same genus, Seriola. Since it is generally known that MABV is acutely pathogenic in yellowtail and related species (Sorimachi \& Hara 1985, Isshiki \& Kusuda 1987, Sano et al. 1998), the current results support such past studies. 
The strain H-1 is an isolate from Japanese flounder, so this strain is pathogenic against species other than its original host. YAV isolated from yellowtail was pathogenic in experimental infection of the Japanese parrotfish Oplegnathus fasciatus, a hybrid of goldstriped amberjack Seriola aureovittata and amberjack (Isshiki \& Kusuda 1987), and spotted parrotfish Oplegnathus punctatus (Nakajima et al. 1998). Thus, the pathogenicity of MABV is not restricted to its original host. MABV can infect various molluskan shellfish, although the pathogenicity against these hosts is not known (Suzuki \& Nojima 1999). Genogrouping based on the amino acid sequence of the variable region VP2/NS part of segment A classified all MABV strains used in this study and the genome from shellfish around Japan into the same group (Hosono et al. 1996, Suzuki \& Nojima 1999). Therefore, the host range of MABV is clearly broad in marine vertebrates and invertebrates.

Infectivity and pathogenicity are clearly different issues. In this study, 5 strains of MABV and IPNV were not virulent for all fish species employed, suggesting that MABV has virulence specificity against the host species. Body size and age of fish are also important factors determining the pathogenicity of fish viruses (Wolf 1988). The varying pathogenicity found in this study might have been influenced by differences in size or age of the fish together with the species specificity. Environmental stressors can alter the pathogenicity of MABV in molluskan shellfish (Chou et al. 1994, 1999, Suzuki et al. 1998b). Stressors can be disregarded in this study because the experimental conditions in all groups were the same, except for water temperature, which was adjusted to the optimum range for each species.

It is well known that a persistent infection of MABV usually occurs in many wild shellfish species. When MABV was in a persistent infection state, the viral genome was detected, but the virus isolation rate was very low (Suzuki \& Nojima 1999). In carrier brook trout Salvelinus fontinalis that was persistently infected with IPNV, release of infectious virus fluctuated $\left(<10^{1.6}\right.$ to $10^{6.0} \mathrm{TCID}_{50} \mathrm{~g}^{-1}$ or $\mathrm{ml}^{-1}$ ) in the absence of external signs (Hedrick \& Fryer 1982). However, in the present study, it is unclear whether the infection was persistent in the host fish. No evidence of persistent infection of MABV in marine fish has ever been reported. Electron microscopy and indirect fluorescent antibody technique have confirmed that MABV replicate in Japanese pearl oyster, but the infectivity titer was low $\left(10^{2.7}\right.$ to $10^{5.1}$ $\mathrm{TCID}_{50} \mathrm{~g}^{-1}$ ) (Kitamura et al. 2000). Thus, it is possible that the reisolated virus strains were replicating actively not only in host fish with a higher infectivity titer but also in host fish with a lower infectivity titer.

The virus isolation rate and the infectivity titer differed among experimental groups with different fish- virus combinations, as shown in Figs $1 \& 2$. The differences were observed among groups with the same fish species or with the same virus strain, indicating the influence(s) of a strain or species factor. All virus strains used in this study had different origins. Strains Y-6, Y-10K and KMKBV-9701 had high isolation rates and infectivity titers in each original host (yellowtail, amberjack and makogarei, respectively), suggesting that the different origins influenced the virus infectivity as a strain factor. The isolation rate of strain AY-98, which originated from ayu, was higher in all fish species, as shown in Fig. 1. Although AY-98 is strongly pathogenic against ayu (Jung et al. 2001), it was not lethal to any fishes tested here. Ayu is an anadromous fish that hatches in rivers, migrates in coastal areas and then ascends rivers to grow. It seems likely that MABV infects ayu in the sea-living phase (Jung et al. 1999). Ayu is probably a permissive host for MABV, and the viruses that replicate in ayu might be able to infect many other natural hosts. MABV probably is distributed around coastal areas and has many natural hosts.

The cases in makogarei and tiger puffer were different from others and were contrary to each other. All virus strains were isolated from makogarei with isolation rates of $>92 \%$, and the mean of infectivity titer was high $\left(10^{5}\right.$ to $\left.10^{6} \mathrm{PFU} \mathrm{g}^{-1}\right)$ relative to that of the other fish species. All strains replicate well in makogarei without clinical signs. These observations strongly suggest that the makogarei is a reservoir of MABV. In contrast, tiger puffer had low infectivity titers for all virus strains, including TP-93, that originated from tiger puffer. TP-93 had no lethal effect against this species by experimental infection. This suggests that MABV replicates slightly in tiger puffer, which tends not to be a permissive host for MABV. Thus, MABV possesses diverse infective states in various marine fish species.

IPNV also replicated well in makogarei and slightly in other marine fish species with no lethal effect. The virus isolation rates and infectivity titers were similar to or higher than those of non-virulent strains of MABV, even though IPNV is a primary pathogen of salmonid fishes. It is possible that marine fish are natural hosts of MABV. In acute disease, viral ascites caused by MABV occurred in the early 1980s in yellowtail in Japan (Sorimachi \& Hara 1985). However, in recent years, this disease has not seriously affected fish stocks (Nakajima et al. 1998). Unlike IPNV, MABV should have many opportunities to infect various marine host species and should not cause damage to the hosts to develop the infection cycle in the marine environment. Therefore, decreased virus multiplication and pathogenicity may be strategies that enable MABV to survive in various hosts.

In conclusion, the infectivity of MABV is considered to change, which is an important factor in the develop- 
ment of the infection cycle of this virus among marine organisms. Suzuki \& Nojima (1999) have reported that $74 \%$ of MABV strains from wild shellfish species have a 126th base genomic mutation that may be shellfish specific. An in vitro study found 1 specific nucleotide change at 195 in subcultured MABVs in CHSE-214, RTG-2 and BF-2 cells but not in EPC and FHM cells (Jung 1998). Our results and their reports suggest that the host specificity of MABV may change together with some genomic mutation throughout replication among different host cells. Further genetic studies on the host specific mutation of MABV that can influence host selectivity or pathogenicity are needed to clarify the mechanism of the aquabirnavirus infection cycle among various host animals.

Acknowledgements. We thank the staff of Yashima Station of the Japan Sea-Farming Association and the Kagawa Prefectural Sea-Farming Center for providing the experimental fish used in this study. Professor K. Kawai, Kochi University, is thanked for his encouragement throughout this study. We thank Dr John Bower, Hokkaido University, for his critical review of this manuscript. This study was partly supported by a Grant-in-Aid from MESSC, Japan.

\section{LITERATURE CITED}

Chou HY, Li HJ, Lo CF (1994) Pathogenicity of a birnavirus to hard clam (Meretrix lusoris) and effect of temperature stress on its virulence. Fish Pathol 29:171-175

Chou HY, Peng TY, Chang SJ, Hsu YL, Wu JL (1999) Effect of heavy metal stressors and salinity shock on the susceptibility of grouper (Epinephelus sp.) to infectious pancreatic necrosis virus. Virus Res 63:121-129

Dobos P, Berthiaume L, Leong JA, Kibenge FSB, Muller H, Nicholson BL (1995) Family Birnaviridae. In: Murphy FA, Fauquet CM, Bishop DHL, Ghabrial SA, Jarvis AW, Martelli GP, Mayo MA, Summers MD (eds) Virus taxonomy: the classification and nomenclature of viruses. Sixth Report of the International Committee on Taxonomy of Viruses. Springer-Verlag, Vienna, p 240-244

Hedrick RP, Fryer JL (1982) Persistent infection of salmonid cell lines with infectious pancreatic necrosis virus (IPNV): a model for the carrier state in trout. Fish Pathol 16: $163-172$

Hosono N, Suzuki S, Kusuda R (1994) Evidence for relatedness of Japanese isolate of birnaviruses from marine fish to IPNV. J Fish Dis 17:433-437

Hosono N, Suzuki S, Kusuda R (1996) Genogrouping of birnaviruses isolated from marine fish: a comparison of VP2/NS junction regions on genome segment A. J Fish Dis 19:295-302

Isshiki T, Kusuda R (1987) Susceptibility of different marine fish fingerlings to yellowtail ascites virus (YAV). Fish Pathol 22:191-194 (in Japanese with English abstract)

Isshiki T, Kawai K, Kusuda R (1989) Incidence of yellowtail ascites virus (YAV) in wild yellowtail fingerling. Nippon Suisan Gakkaishi 55:633-637 (in Japanese with English abstract)

Jung SJ (1998) Change of infection properties of subcultured marine birnavirus in several fish cell lines. J Fish Pathol 11:89-96
Jung SJ, Kitamura SI, Kawai K, Suzuki S (1999) Isolation of different types of birnavirus from ayu Plecoglossus altivelis and amago salmon Oncorhynchus rhodurus cultured in the same geographic area. Dis Aquat Org 38: $87-91$

Jung SJ, Suzuki S, Oh MJ, Kawai K (2001) Pathogenicity of marine birnavirus against ayu Plecoglossus altivelis. Fish Pathol 36:99-101

Kamakura M, Suzuki S, Kusuda R (1995) Characterization of birnavirus isolated from diseased tiger puffer. Ann Meet Jpn Soc Fish Pathol, Mie, Japan, September 1995, abstract p 14 (in Japanese)

Kitamura SI, Jung SJ, Suzuki S (2000) Seasonal change of infective state of marine birnavirus in Japanese pearl oyster Pinctada fucata. Arch Virol 145:2003-2014

Kusuda R, Kado K, Takeuchi Y, Kawai K (1989) Characteristics of two virus strains isolated from young Japanese flounder Paralichthys olivaceus. Suisanzoshoku 37: 115-120 (in Japanese with English abstract)

Kusuda R, Nishi Y, Hosono N, Suzuki S (1993) Serological comparison of birnaviruses isolated from several species of marine fish in south west Japan. Fish Pathol 28:91-92

Kusuda R, Nagato K, Kawai K (1994) Characteristics of a virus isolated from red sea bream, Pagrus major showing exophthalmos. Suisanzoshoku 42:145-149 (in Japanese with English abstract)

Lannan CN, Winton JR, Fryer JL (1984) Fish cell lines: establishment and characterization of nine cell lines from salmonids. In Vitro 20:671-676

Nakajima K, Maeno Y, Arimoto M, Inoue K, Sorimachi M (1993) Viral deformity of yellowtail. Fish Pathol 28: 125-129 (in Japanese with English abstract)

Nakajima K, Inouye K, Sorimachi M (1998) Viral diseases in cultured marine fish in Japan. Fish Pathol 33:181-188

Russell WC (1962) A sensitive and precise plaque assay for herpes virus. Nature 195:1028-1029

Sano M, Hukuda H, Minagawa M, Hayashibara T, Tamaki M, Hirokawa J, Sugiyama A, Kitano T, Nakajima K (1998) Susceptibility of marine fish species cultured in subtropical areas of Japan against yellowtail ascites virus. Ann Meet Jpn Soc Fish Pathol, Tokyo, Japan, March 1998, abstract p 21 (in Japanese)

Sorimachi M, Hara T (1985) Characteristics and pathogenicity of a virus isolated from yellowtail fingerlings showing ascites. Fish Pathol 19:231-238 (in Japanese with English abstract)

Suzuki S, Nojima M (1999) Detection of a marine birnavirus in wild molluscan shellfish species from Japan. Fish Pathol 34:121-125

Suzuki S, Hosono N, Kusuda R (1997a) Detection of aquatic birnavirus gene from marine fish using a combination of reverse transcription- and nested PCR. J Mar Biotechnol 5: 205-209

Suzuki S, Nakata T, Kamakura M, Yoshimoto M, Furukawa Y, Yamashita Y, Kusuda R (1997b) Isolation of birnavirus from Agemaki (jack knife clam) Sinonovacura constricta and survey of the virus using PCR technique. Fish Sci 63: 563-566

Suzuki S, Kamakura M, Kusuda R (1998a) Isolation of birnavirus from Japanese pearl oyster Pinctada fucata. Fish Sci 64:342-343

Suzuki S, Utsunomiya I, Kusuda R (1998b) Experimental infection of marine birnavirus strain JPO-96 to Japanese pearl oyster Pinctada fucata. Bull Mar Sci Fish Kochi Univ 18:39-41

Wolf K (1988) Fish viruses and fish viral disease. Cornell University Press, New York 